\title{
New data on the poorly-known Late Jurassic European turtles Thalassemys and Enaliochelys and description of a new basal eucryptodiran taxon
}

\author{
A. Pérez-García ${ }^{1,2}$ \\ ${ }^{1}$ Centro de Geologia, Faculdade de Ciências da Universidade de Lisboa (FCUL), Edificio C6, Campo Grande, \\ 1749-016 Lisbon, Portugal. \\ ${ }^{2}$ Grupo de Biología Evolutiva, Facultad de Ciencias, UNED, Senda del Rey, 9, 28040 Madrid, Spain. \\ e-mail address: paleontologo@gmail.com
}

Received: 22 December 2013 / Accepted: 18 December 2014 / Available online: 25 March 2015

\begin{abstract}
One of the most abundant clades of turtles in the Late Jurassic record of Europe is Eucryptodira, represented by Plesiochelyidae, Eurysternidae, Hylaeochelys and Thalassemys. The detailed study of a British specimen preliminarily attributed to the plesiochelyid "Pelobatochelys" allows this attribution to be refuted. Rather, it is recognized as the only confirmed specimen of the genus Thalassemys outside Central Europe. The diversity of Eucryptodira in the Late Jurassic of Europe is here increased, thanks to the revision of two problematic specimens, not assignable to any of the four above mentioned taxa. Enaliochelys chelonia, is a poorly-known British taxon ignored since the late nineteenth century because of its putative synonymy with Thalassemys hugii. The validity of this taxon is supported here and a diagnosis for it is proposed for the first time. The other specimen, from France (Oléron Island), was previously attributed to "Thalassemys moseri", which is currently considered invalid. It is recognized as a representative of a new taxon, Jurassichelon oleronensis gen. et sp. nov.

Keywords: Late Jurassic, Europe, Eucryptodira, Thalassemys, Enaliochelys chelonia, Jurassichelon oleronensis gen. et sp. nov.

Resumen

Uno de los clados de quelonios más abundantes en el registro del Jurásico Superior de Europa es Eucryptodira, representado por Plesiochelyidae, Eurysternidae, Hylaeochelys y Thalassemys. El estudio detallado de un ejemplar británico preliminarmente atribuido a "Pelobatochelys" (Plesiochelyidae) permite refutar esta atribución, reconociéndose como la única referencia confirmada del género Thalassemys fuera de Europa Central. La diversidad de Eucryptodira del Jurásico Superior de Europa es aquí incrementada, gracias a la revisión de dos ejemplares problemáticos, no asignables a ninguno de los cuatro taxones citados. Enaliochelys chelonia es un taxón británico muy mal conocido, que ha sido ignorado en la literatura desde finales del siglo XIX, cuando fue erróneamente clasificado como sinónimo de Thalassemys hugii. La validez de este taxón es aquí apoyada, formulándose, por primera vez, una diagnosis para el mismo. El otro ejemplar, procedente del registro francés (Isla de Oléron), fue atribuido a "Thalassemys moseri", actualmente considerado como no válido. Dicho ejemplar se reconoce aquí como un representante de un nuevo taxón, Jurassichelon oleronensis gen. et sp. nov.
\end{abstract}

Palabras clave: Jurásico Superior, Europa, Eucryptodira, Thalassemys, Enaliochelys chelonia, Jurassichelon oleronensis gen. et sp. nov.

\section{Introduction}

During the Kimmeridgian and Tithonian (Late Jurassic), Eucryptodira, represented today by the cryptodiran turtes (i.e. the most abundant and diverse clade of turtles living today), experienced a spectacular radiation in Europe (Lapparent de Broin et al., 1996; Pérez-García, 2014; Pérez-García and Ortega, 2014). Four defined taxa are involved: the abundant and diverse Plesiochelyidae and Eurysternidae, the recently identified Hylaeochelys Lydekker, 1889a, and the poorlyknown Thalassemys Rütimeyer, 1873 (Lapparent de Broin, 2001; Pérez-García and Ortega, 2014). The inhabitants of coastal environments Plesiochelyidae, Eurysternidae and Thalassemys are only known in the Late Jurassic (from the Oxfordian to the Tithonian), while the probably freshwater Hylaeochelys is well represented in the Valanginian (Early 
Cretaceous), having survived the regressions experienced in the shallow shelf seas of Europe, which have been identified as responsible for the disappearance of these coastal forms, drastically reducing their habitats (Bardet, 1994; Pérez-García, 2012; Pérez-García and Ortega, 2014).

Information about Thalassemys is currently very limited. Its type species, Thalassemys hugii Rütimeyer, 1873, only known by a described specimen from the Late Kimmeridgian of Solothurn (Switzerland) (Figs. 1, 2), is the only taxon confirmed as attributable to both this genus and to the clade Thalassemydidae (Lapparent de Broin, 2001). Several species were preliminarily attributed to Thalassemys, but are currently identified as representatives of several clades, such as members of Eurysternidae (e.g. "Thalassemys" marina Fraas, 1903, from the Late Jurassic of Bade-Würtemberg, Germany), Plesiochelyidae ("Thalassemys moseri" Bräm, 1965, from the Late Kimmeridgian of Solothurn, Switzerland; now identified as a junior synonym of Plesiochelys solodurensis), and representatives of Paracryptodira (e.g. "Thalassemys ruetimeyeri" Lydekker, 1889b, from the Berriasian of Dorset, England; now recognized as a junior synonym of the pleurosternid Dorsetochelys typocardium (Seeley, 1869)) (Lapparent de Broin et al., 1996; Lapparent de Broin, 2001; Pérez-García, 2014; Pérez-García et al., 2015). This latter was not the only reference to Thalassemys in the British record. Lydekker (1889b) erroneously considered Enaliochelys chelonia Seeley, 1869, probably from the Early Kimmeridgian of Ely (Cambridgeshire) (Fig. 1), to be an invalid taxon, recognizing it as a synonym of Thalassemys hugii. In addition, he attributed to Thalassemys hugii several fragments of plates, from the Kimmeridge Clay of Devizes (Wiltshire) (Fig. 1), that could correspond to a single specimen (NHMUK 46326 and NHMUK 47327), and also a femur probably associated to it (NHMUK 46328). However, these specimens have never been described nor figured, and these attributions were not justified. This lack of information has prevented confirmation of the hypothesis proposed by Lydekker (1889b). Although some papers published in the early years of the twentieth century reaffirmed the idea of the synonymy proposed by Lydekker (1889b) (e.g. Zittel, 1902; Lydekker, 1904), without providing any new information, the material from Ely has been generally ignored in the subsequent papers. Therefore, the currently available data does not allow the presence of Thalassemys in the British record to be recognized (see Lapparent de Broin, 2001).

A relatively complete carapace of a turtle, from Egmont Bight, in the West coast of the Isle of Purbeck (Dorset, England) (Fig. 1), is presented here: NHMUK R8699. It comes from the Late Kimmeridgian of the Kimmeridge Clay Formation (Taylor and Benton, 1986). This specimen also preserves elements corresponding to the scapular and pelvic girdles, and some appendicular bones. Despite its good preservation and potential interest, this specimen, collected about 1968, has never been described or figured. Taylor and Benton (1986) cited its presence but they did not refute its attribu- tion to "Pelobatochelys" Seeley, 1875 mentioned on the label corresponding to this specimen. In fact, these authors indicated that, if this specimen is correctly assigned to the so far poorly known "Pelobatochelys", it constitutes the first record of limb elements of this genus. Pérez-García (2013) recently indicated that this specimen differs from "Pelobatochelys" blakii Seeley, 1875, but also from the other basal members of Eucryptodira identified in the British record (e.g., Tholemys passmorei Andrews, 1921, from the Late Jurassic of Swindon, Wiltshire), sharing several characters with the Swiss Thalassemys hugii. These preliminary observations justify the potential interest of the study of this specimen, which is described and analyzed in detail in this paper.

The analysis of the characters shared between NHMUK R8699 and the holotype of Thalassemys hugii, and that of other characters not preserved in the English specimen provide new data on two specimens previously referred or analyzed by other authors, and their systematic position is reviewed here. One of them is the cited holotype of Enaliochelys chelonia. New material of its type locality is also presented here. The other one is a specimen from the Ile d'Oléron (Western France) (Fig. 1), identified by Rieppel (1980) as a representative of the currently considered invalid "Thalassemys moseri".

Institutional abbreviations: CAMSM, Sedgwick Museum, Department of Geology, University of Cambridge, UK; NHMUK, Natural History Museum, London, UK; PMZH, Palaeontological Museum, University of Zurich, Switzerland.

\section{Confirmation of the presence of Thalassemys in the British record}

Testudines Batsch, 1788

Pancryptodira Joyce, Parham and Gauthier, 2004

Eucryptodira Gaffney, 1975a

Thalassemydidae Zittel, 1889

Thalassemys Rütimeyer, 1873

Type species: Thalassemys hugii Rütimeyer, 1873 (Fig. 2)

Thalassemys sp.

(Fig. 3)

Material: NHMUK R8699, a specimen preserving most of the carapace except the nuchal plate and several peripherals, the partial pelvis, the left scapula, both ulnae, the right tibia, and several poorly-preserved remains of the caudal vertebrae.

Locality and horizon: Egmont Bight, west coast of the Isle of Purbeck, Dorset, England (Fig. 1); Upper Kimmeridgian, Kimmeridge Clay Formation; Paravirgatus Subzone of the Pectinatus Zone (Taylor and Benton, 1986).

Description: The carapace of the specimen NHMUK R8699 is longer than wide, its maximum width being located in its anterior half (Fig. 3 A-B). Its length is estimated to be 


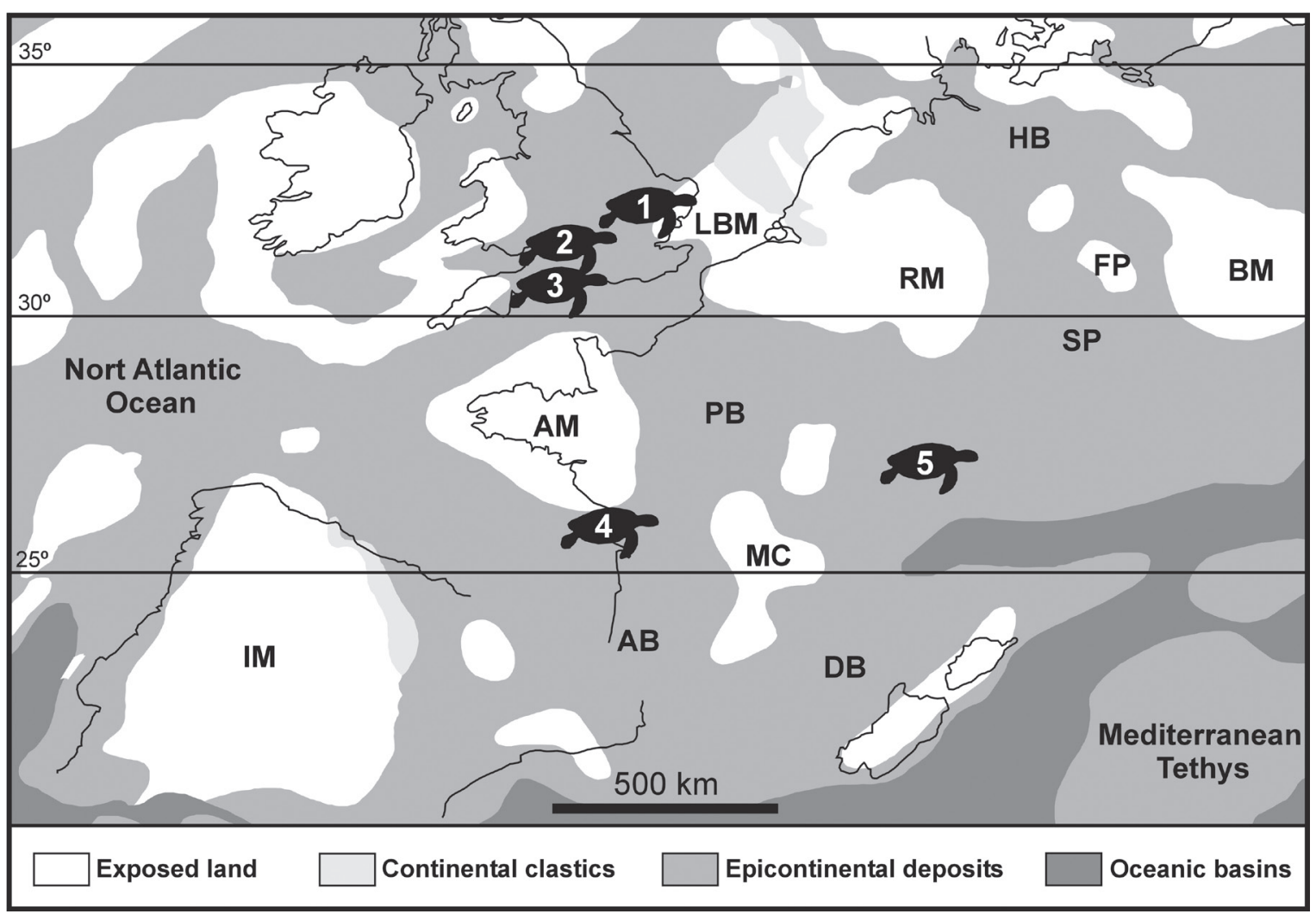

Fig. 1.- Map of Western Europe during the early Kimmeridgian showing the locations where the main turtle specimens discussed in this paper were found. Modified from Püntener et al. (2014). Numbers: 1, Ely, Cambridgeshire, England; 2, Devizes, Wiltshire, England; 3, Egmont Bight, Isle of Purbeck, Dorset, England; 4, La Morelière, Oléron Island, France; 5, Solothurn, Switzerland. Abbreviations: AB, Aquitaine Basin; AM, Armorican Massif; BM, Bohemian Massif; DB, Dauphinois Basin; FP, Franconian Platform; HB, Hannover Basin; IM, Iberian Massif; LBM, London Brabant Massif; MC, Massif Central; PB, Paris Basin; RM, Rhenish Massif; SP, Swabian Platform.

around $50 \mathrm{~cm}$. This specimen lacks sagittal keel. It preserves the complete neural series, composed of eight plates. All of them, except the last one, are markedly longer than wide. The first neural is subrectangular. The second to seventh neurals are hexagonal, with very short antero-lateral margins. The eighth neural is subrounded, almost as wide as long. This specimen has three suprapygal plates. The morphology of the first one is not well-known. The second and third suprapygals are very wide, the second one being the widest. NHMUK R8699 has eight pairs of costal. The first pair is relatively short, its length being slightly greater than that of the second pair. The lateral margin of the costal plates was in contact with fontanelles. The posterior peripheral plates are short relative to their width.

The first dorsal rib is long and is not fused to the second one, but both ribs are laterally in contact (Fig. 3C-E).

The vertebral scutes are wide, their width being about twice their length. Sagittally, the boundaries between the vertebrals are placed on the first, third and fifth neurals, and on the first suprapygal. The lateral margins of the first vertebral scute are divergent towards the anterior end of the carapace. The other vertebrals are hexagonal. The widths of the second to fourth vertebrals are similar to each other. For this reason, the boundary between the third and fourth pleural scutes do not overlaps the costal series.
The two ilia, partially articulated with the ischia, are preserved. These bones, as well as some elements corresponding to caudal vertebrae, have not been separated from the posterior region of the visceral area of the carapace (Fig. 3C-D, Q). The proximal half of the left ulna is preserved, but it is also situated in the visceral region of the specimen (Fig. 3C-D, F). The partial left scapula, and the complete right ulna and right tibia have been separated from this block. The angle formed by the two processes of the scapula, the dorsally projected scapular process and the ventromedially projected acromial process, is around 115 degrees (Fig. 3O-P). Both processes are relatively flat. The area corresponding to the glenoid cavity is not preserved. Both the ulnae as the tibiae are dorsoventrally flattened (Fig. 3 F-N). These bones are slightly curved. Distally, the ulnae have two approximately equal in size articular surfaces for the carpal articulation. The ulnae are expanded at both the proximal and distal ends to approximately twice the width of their shaft. A similar expansion is observed in the proximal region of the tibia, but not in the distal one.

\section{Discussion}

As has been recently discussed (Pérez-García, 2013), the absence of a sagittal keel on the carapace of NHMUK R8699 (a character recognized as exclusive of Tropidemys) refutes 


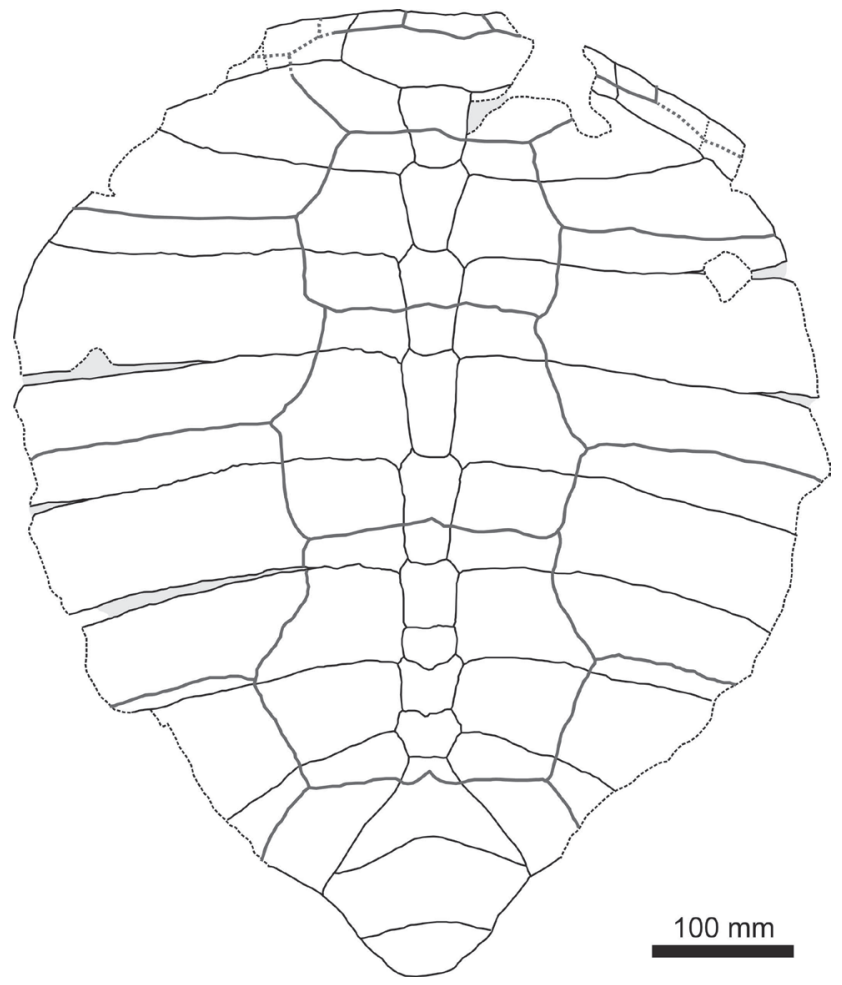

Fig. 2.- Dorsal view of the carapace of the holotype of Thalassemys hugii, from the late Kimmeridgian of Solothurn, Switzerland. The black lines represent the osseous elements, the grey lines correspond to the border of the scutes, and gray surfaces indicate the areas covered by sediment.

its attribution to the plesiochelyid "Pelobatochelys" blakii as suggested by Taylor and Benton (1986), a taxon also defined in the Kimmeridgian of the Kimmeridge Clay Formation of Dorset. In fact, other characters such as the presence of long and narrow neurals are not shared with the species of the genus Tropidemys. The attribution of NHMUK R8699 to Plesiochelyidae (see Taylor and Benton, 1986) is refuted here.

Knowledge about the appendicular elements of the basal members of Eucryptodira from the Late Jurassic of Europe is very limited: none of these elements have been described in the two known species of Hylaeochelys, only few appendicular bones of Thalassemys are known, and the so far available informations on these bones in Eurysternidae and Plesiochelyidae is limited to few taxa (e.g. a detailed described specimen of the eurysternid Solhofia parsonsi Gaffney, 1975b, see Joyce, 2000). The information on the character states discussed here is based on personal observations, as well as in that available in several papers, among which are those of Lapparent de Broin et al. (1996), Joyce (2007), Sterli and Fuente (2011), Tong et al. (2012), Pérez-García and Murelaga (2012), Pérez-García and Ortega (2014), Pérez-García (2014), Pérez-García et al. (2014).

Xinjiangchelyidae, a turtle clade considered as having originated in Asia, have been identified in the Early Cretaceous of Europe but not in the Late Jurassic of this continent (see Pérez-García et al., 2014).. Several characters exclude NHMUK R8699 from the clade Xinjiangchelyidae (e.g. its size, which is larger than that of the members of this clade; the absence of a domed shell; the absence of transversely expanded posterior peripherals; the absence of overlapping of the fourth to seventh marginal scutes on the costal series; the absence of sagittal contact in the last pairs of costal plates).

The presence of a low shell in NHMUK R8699 is shared with Thalassemys hugii, Eurysternidae, and the two known species of Hylaeochelys (the Late Jurassic H. kappa PérezGarcía and Ortega, 2014, and the Early Cretaceous H. belli (Mantell, 1844)), but not with Plesiochelyidae. The carapace plates are thinner than those observed in Plesiochelyidae, a character state shared with Thalassemys hugii, Eurysternidae and Hylaeochelys. The presence of short posterior peripherals is shared with Thalassemys hugii and Plesiochelyidae, but not with Eurysternidae and Hylaeochelys. The presence of lateral margins of the first vertebral scute that diverge towards the anterior region of the carapace differs from the condition observed in Hylaeochelys. The angle formed by the two processes of the scapula, greater than that in Plesiochelys, is similar to that recognized in the holotype of Thalassemys hugii, as well as in the members of Eurysternidae (e.g. Solhofia parsonsi and Eurysternum ignoratum Bräm, 1965).

In addition to the combination of characters discussed above, NHMUK R8699 shares with Thalassemys hugii, but not with Plesiochelyidae, Eurysternidae or Hylaeochelys, the presence of three suprapygal plates. The morphology of the posterior half of the first one is not well-known. However, as in Thalassemys hugii, the second is wider than the last one. The cordiform morphology of the shell of NHMUK R8699 is shared with Thalassemys hugii, and differs from that of the other taxa.

NHMUK R8699 differs from the holotype of Thalassemys hugii in several characters. Its vertebral scutes are remarkably wider. The lateral margin of the fourth vertebral of NHMUK R8699 overlaps a region corresponding to the fontanelles. The fontanelles of this specimen, located between the costal and the peripheral plates, are well developed. This contrasts with the condition seen in Thalassemys hugii, where the fontanelles are narrower. The reduction or loss of the carapace fontanelles, as well as the narrowing of the vertebral scutes, are characters that generally vary during the ontogenetic development. Therefore, given that the estimated size for the complete shell of NHMUK R 8699 is about $70 \%$ of that of the holotype of Thalassemys hugii, these different states of character cannot be justified as indicative of specific differences. The observed differences in the morphology of the vertebral scutes of both specimens, in the relative width of the neural plates, and in the morphology of the first neural, are characters that have been recognized as subject to individual variability in other European basal members of Eucryptodira (e.g. in Hylaeoechelys belli and Brodiechelys brodie, see PérezGarcía, 2012).

Therefore, the available information on the specimen $\mathrm{NH}-$ MUK R8699 allows its attribution to the genus Thalassemys. A specific determination is not possible because of the above 

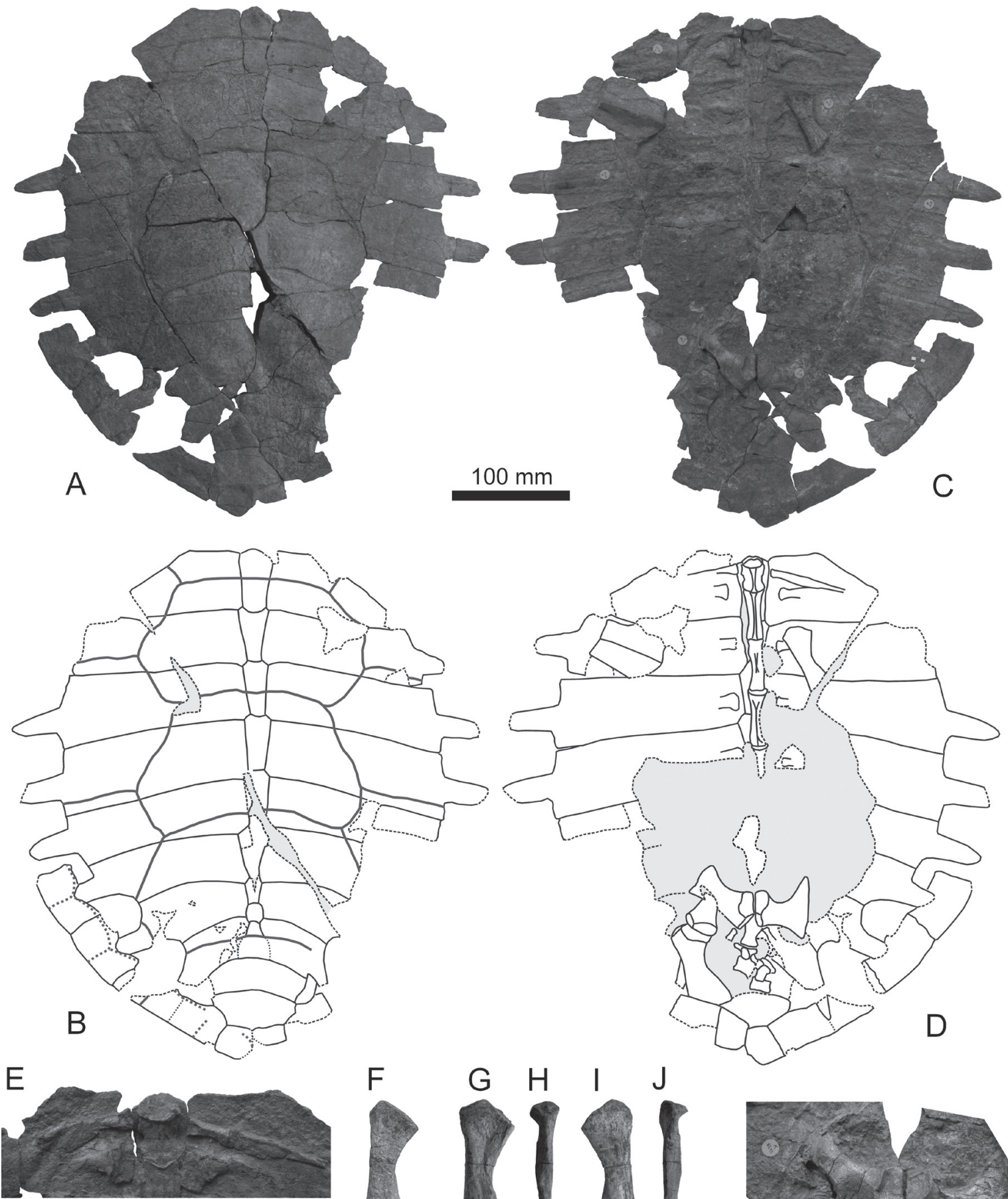

$\mathrm{F}$
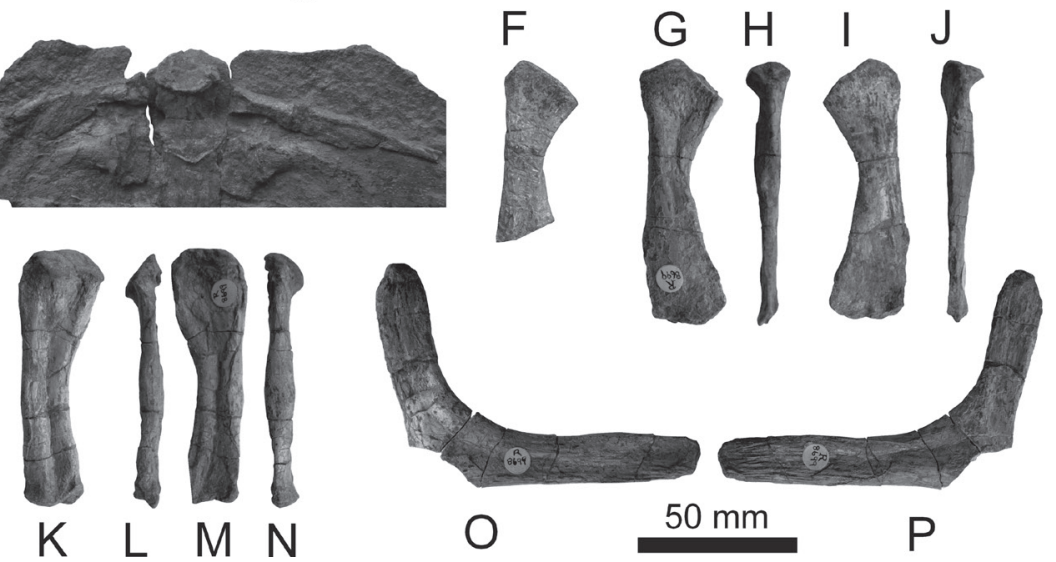

O

$50 \mathrm{~mm}$

$\mathrm{P}$

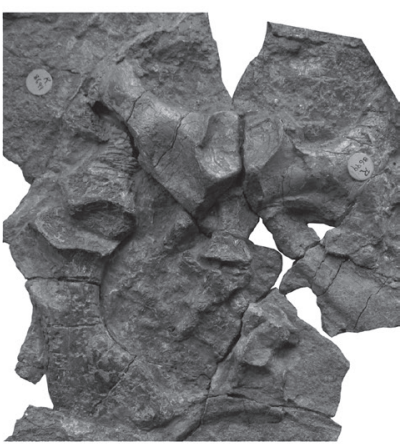

Q

Fig. 3.- NHMUK R8699, Thalassemys sp. from the late Kimmeridgian of Egmont Bight, in the West coast of the Isle of Purbeck, Dorset, England. A-D, Carapace, in dorsal (A-B) and ventral (C-D) views; E, detail of the anterior region of the carapace, in visceral view, where the first two pairs of dorsal ribs can be identified; F, left ulna; G-J, right ulna; K-N, right tibia; O-P, left scapula; Q, detail of the posterior region of the carapace, in visceral view, where some elements corresponding to the pelvic girdles are preserved. The black lines represent the osseous elements, the grey lines correspond to the border of the scutes, and the gray surfaces indicate the areas covered by sediment. Institutional abbreviation: NHMUK, Natural History Museum, London, UK. 
mentioned problems. This, however, confirms the occurrence of this genus in Late Kimmeridgian outcrops outside of the type locality of Solothurn (Switzerland).

\section{Analysis of the validity of the turtle taxon defined by Seeley (1869) in the Kimmeridge Clay Formation of Ely (England)}

Testudines Batsch, 1788

Pancryptodira Joyce, Parham and Gauthier, 2004

Eucryptodira Gaffney, 1975a

Enaliochelys Seeley, 1869

Type and only species: Enaliochelys chelonia Seeley, 1869

Diagnosis: As for the type species

Enaliochelys chelonia Seeley, 1869

(Figs. 4A-J, Q-X)

Synonyms: Enaliochelys chelonia Seeley, 1869; Thalassemys hugii Rütimeyer, 1873 in Lydekker 1889b.

Holotype: A partial postcranial disarticulated skeleton corresponding to numbers CAMSM J29898 to CAMSM J29955 (Fig. 4A-J).

Referred material: CAMSM J29960, CAMSM J29961, CAMSM J29964, CAMSM J29965, several fragments of costal plates and of the free region of the dorsal ribs, all of them from the type locality and horizon (Fig. 4Q-X).

Type locality and horizon: Ely, Cambridgeshire, England (Fig. 1); Kimmeridge Clay Formation, probably Early Kimmeridgian (Benson et al., 2013).

Emended diagnosis: Basal member of Eucryptodira, more than $60 \mathrm{~cm}$ in length, possessing well-developed free regions of the dorsal ribs, which correspond to more than three quarters of the width of the last pair of costals, and sharing the following character combination: absence of nuchal notch; presence of a single cervical scute; very wide vertebral scutes; wide fontanelles between the costal and the peripheral plates; robust and high plastral processes; angle formed by the scapular and the acromial processes of the scapula around 110 degrees.

\section{Description}

The only specimen hitherto attributed to Enaliochelys chelonia (see Seeley, 1869) corresponds to several elements of a postcranial skeleton, including numerous carapace plates (see some of them in Fig. 4A-B). It lacks a nuchal notch. The first neural, subcircular, is about as wide as long. The remaining neurals are hexagonal, having antero-lateral margins significantly shorter than postero-lateral ones. A suprapygal, twice as wide as it is long, is preserved. The free region of the dorsal ribs is very well developed. In fact, it constitutes a high proportion of the costals, especially of the last pairs. Very wide fontanelles are developed between these plates and the peripheral series. This taxon has only a cervical scute.
The vertebral scutes are very wide. The plastral buttresses are high and very robust. Other undetermined fragments of plates, generally corresponding to elements of the plastron, some vertebrae, elements corresponding to the scapular and pelvic girdles, and appendicular bones, are also preserved (see some of them in Fig. 4C-J).

\section{Discussion}

Although Seeley (1869) considered the above mentioned partial skeleton from Ely as belonging to a new taxon, Enaliochelys chelonia, Lydekker (1889b) reassigned it to Thalassemys hugii. Since that specimen has never been figured, described or discussed, none of these hypotheses have been so far confirmed. The study of this specimen confirms that it is different from Thalassemys hugii, and supports the validity of Enaliochelys chelonia for which a diagnosis is proposed here for the first time.

The estimated length of this specimen from Ely is similar to that of the holotype of Thalassemys hugii. However, it differs from Thalassemys due to numerous characters, including: the presence of very wide fontanelles between the costal and peripheral plates, with the free region of the dorsal ribs being very wide relative to the width of these plates, especially the last pairs of costals; absence of the carapace cordiform morphology characteristic of Thalassemys; very wide vertebral scutes; different morphology of the preserved suprapygal; much robust and higher plastral buttresses.

Characters such as, among others, its larger size, the absence of lateral plastral fontanelles and the more developed plastral buttresses allows Enaliochelys chelonia to be differentiated from the eurysternids.

This taxon differs from Hylaeochelys, and from the taxon of the Oléron Island, in the absence of a nuchal notch. The specimen from Ely differs from the roughly circular morphology of the shell of Hylaeochelys. Furthermore, its plates are thicker than those of Hylaeochelys, and it also lacks the slightly fluted carapace surface present in Hylaeochelys. The presence of a cervical scute differs from the condition present in the taxon from the Oléron Island, where this scute is absent, and in Plesiochelyidae, where it is divided into three scutes. In addition, the vertebral scutes of the taxon from Ely are significantly wider than those of Plesiochelyidae and of the taxon from the Oléron Island. The great development of the free region of the dorsal ribs observed in the taxon from Ely, together with the reduction in width of the other region of the costal plates, differs from the condition present in the taxon from the Oléron Island, Hylaeochelys and Plesiochelyidae. Finally, the presence of fontanelles between the costal and the peripheral plates is not shared with Hylaeochelys or Plesiochelyidae.

The angle formed by the two processes of the scapula of the specimen from Ely is similar to that recognized in Thalassemys and it is also consistent with the known variability observed in Eurysternidae. However, the information on the 
variability present in Plesiochelyidae is very limited, and this bone is not known in Hylaeochelys or in the taxon from the Oléron Island. The information on the coracoid or on the elements of the pelvic girdle, bones of the fore and hind limbs and caudal vertebrae of basal members Eucryptodira is, as indicated, also very limited. A detailed study of these bones in several of these taxa is needed in order to make detailed comparisons and to recognize the relevant characters from a systematic point of view.

The revision of the specimen from Ely allows to support the original attribution to Enaliochelys chelonia by Seeley
(1869) and to refute the Lydekker's one (1889b). This basal Eucryptodira cannot be recognized as a representative of the clades Eurysternidae, Plesiochelyidae, neither attributed to Thalassemys, Hylaeochelys, nor to the taxon from the Oléron Island.

The few fragments of plates from the Kimmeridge Clay of Devizes (Wiltshire) (NHMUK 46326 and NHMUK 47327) attributed to Thalassemys hugii by Lydekker (1889b) have been analyzed. The limited characters available do not allow confirming that systematic atribution. Due to the limited information on the appendicular skeleton of the Eucryptodira

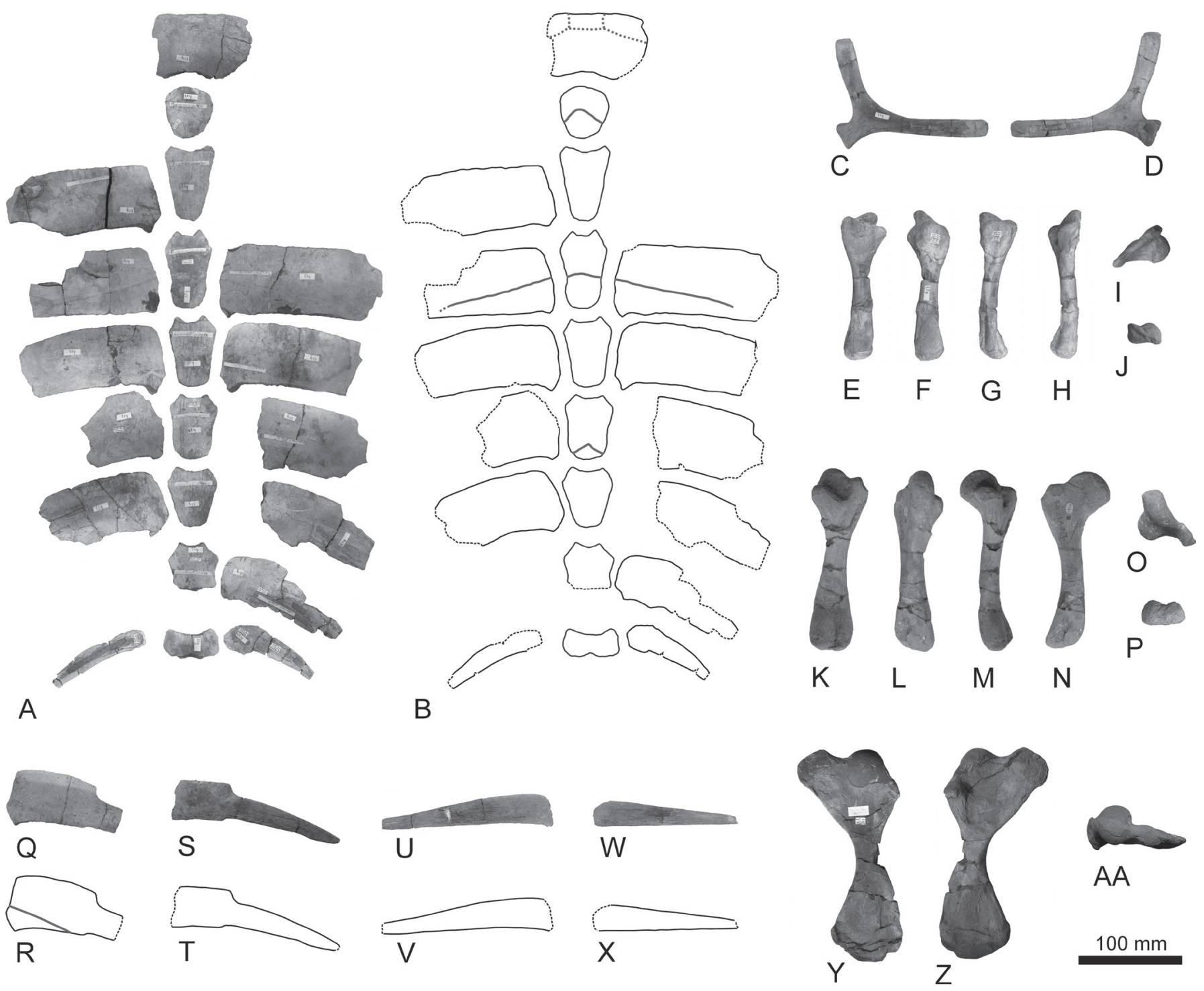

Fig. 4.- British specimens of basal eucryptodiran turtles from the Kimmeridge Clay Formation. A-J, Elements of the holotype of Enaliochelys chelonia, from Ely, Cambridgeshire. A-B, Plates of the carapace, the left costals being, from the anterior to the posterior position in the figure, CAMSM J29914, CAMSM J29907, CAMSM J29915, CAMSM J29937, CAMSM J29911, CAMSM J29955; the nuchal plate being CAMSM J29946; the neurals being, from the anterior to the posterior position in the figure, CAMSM J29905, CAMSM J29898, CAMSM J29902, CAMSM J29900, CAMSM J29899, CAMSM J29903, CAMSM J29901; the pygal plate being CAMSM J29904; the right costals being, from the anterior to the posterior position in the plate, CAMSM J29908, CAMSM J29909, CAMSM J29916, CAMSM J29912, CAMSM J29913. C-D, CAMSM J29918, left scapula. E-J, CAMSM J29921, left femur. K-P, NHMUK 46328, right femur of an indeterminate taxon, from Devizes (Wiltshire), identified by Lydekker (1889b) as Thalassemys hugii. Q-X, Fragments of costal plates from Ely, identified as belonging to Enaliochelys chelonia: CAMSM J29961, CAMSM J29960, CAMSM J29965, CAMSM J29964. Y-AA, CAMSM J29959, right humerus of an indeterminate taxon coming from Ely. The black lines represent the osseous elements and the grey lines correspond to the border of the scutes. Institutional abbreviation: CAMSM, Sedgwick Museum, Department of Geology, University of Cambridge. 
basal members, the femur recognized by Lydekker (1889b) as probably associated to the same individual (NHMUK 46328, Fig. 4K-P) does not provides data of systematic relevance. Therefore, this material is identified as belonging to an indeterminate Eucryptodira basal member, non-assignable to Hylaeochelys due to its thicker plates, or to Eurysternidae due to its larger size.

Other previously unpublished isolated specimens are here attributed to Enaliochelys chelonia. These specimens (CAMSM J29961, CAMSM J29960, CAMSM J29965, CAMSM J29964; Fig. 4Q-X), coming from the type locality and horizon of this taxon, are elements of the carapace, in which the presence of the very long free regions of the dorsal ribs that characterize Enaliochelys chelonia is recognized. Other unpublished elements also from the Kimmeridge Clay Formation of Ely have been found. However, the limited characters available in some of them (e.g. fragments of plates) or the absence of these elements in the holotype of Enaliochelys chelonia (e.g. the humerus CAMSM J29959, Fig. 4Y-AA), do not allow knowing if they correspond to the same taxon.

\section{Revision of the specimen of "Thalassemys moseri" from the Oléron Island (France)}

Testudines Batsch, 1788

Pancryptodira Joyce, Parham and Gauthier, 2004

Eucryptodira Gaffney, 1975a

Jurassichelon oleronensis gen. et sp. nov.

(Figs. 1-6, 8b, 9a, 10a, 11-12, 14-17, 19b in Rieppel, 1980)

Synonyms: Thalassemys moseri (Bräm, 1965) in Rieppel, 1980; "Thalassemys moseri" in Joyce, 2007.

Holotype: PMZH A/III 514, a specimen that preserves the almost complete skull, four cervical vertebrae, the anterior half of the carapace (i.e. the nuchal, the first two pairs of peripherals, the first four neurals, the complete first three right costals, the complete first left costal, and the partial fourth right and second and third left costals), some peripherals, and the anterior half of the plastron (i.e. the complete left hyoplastron, most of the right one except its most anterior region, the most anterior area of the left hypoplastron, and the anterolateral region of the right hypoplastron).

Type locality and horizon: An outcrop near La Morelière, Oléron Island, western France (Fig. 1); Early Tithonian of the Gravesia zone (Rieppel, 1980).

Etymology: The generic name is composed by the words Jurassic, the period in which that turtle lived, and chelone, meaning turtle in Greek. The specific name refers to the Oléron Island (France), where it has been found.

Diagnosis: Basal eucryptodiran turtle lacking cervical scute, the first vertebral scute being in contact with the anterior edge of the carapace, and sharing the following character combination: reduced dorsal prefrontal exposure; absence of prefrontal medial contact on the dorsal skull surface; absence of palatal vomer-pterygoids contact; absence of basiptery- goid process; absence of paired pits on the ventral surface of the basisphenoid; presence of ventral ridge on the opisthotic, being developed an enclosed middle ear region; presence of foramen palatinum posterius, open laterally; foramen jugulare posterius not formed by the exoccipital; foramen caroticum laterale formed by the pterygoids, as is the foramen posterior canalis carotici interni; presence of an extended process anterior to the trigeminal foramen, produced by the inferior parietal process; wide, shallow notch restricted to the anterior margin of the nuchal plate; wider than long first peripherals; relatively long costals compared to their width; relatively straight lateral margin of the second and third costals; first dorsal rib relatively long, not contacting the second one; presence of well-developed fontanelles between the costals and the peripherals; presence of a central plastral fontanelle; absence of lateral plastral fontanelles; relatively wide vertebrals; axillary buttresses in contact with the postero-lateral region of the first pair of peripherals, and overlapped on more than a third of the width of the first pair of costals.

Description: See Rieppel (1980).

\section{Discussion}

Although PMZH A/III 514 was attributed to "Thalassemys moseri" by Rieppel (1980), subsequent papers refuted that attribution (see, for example Lapparent de Broin et al., 1996; Joyce, 2007), identifying it as an undefined basal new member of Eucryptodira. The revision of Thalassemys confirms that PMZH A/III 514 cannot be assigned to this taxon due to characters such as: its highest shell; the different morphology of its shell, the costal series being narrower in relation to its length, with more rectilinear lateral margins of the costals, and having a nuchal notch; the absence of cervical scute, its first vertebral scute being in contact with the anterior edge of the carapace; the lower angle of divergence of the lateral margins of the first vertebral; the presence of second and third vertebral wider in relation to the width of the costal plates; the smallest angle of the axillary notch; the presence of much more robust and high axillary buttresses, contacting the postero-lateral regions of the first pair of peripherals and the lateral edges of the first pair of dorsal ribs.

This basal representative of Eucryptodira shares with the Late Jurassic European taxa for which the skull is known (e.g. the eurysternid Solnhofia parsonsi Gaffney, 1975b; the plesiochelyids Plesiochelys planiceps (Owen, 1842), Plesiochelys solodurensis Rütimeyer, 1873, and Portlandemys mcdowelli Gaffney, 1975c), but not with Xinjiangchelyidae (e.g. Xinjiangchelys latimarginalis (Young and Chow, 1953)): absence of basipterygoid process, absence of paired pits on the ventral surface of the basisphenoid; foramen jugulare posterius not formed in bone. In addition, it also shares with the basal members of Eucryptodira from the Late Jurassic of Europe, but not with Xinjiangchelyidae: presence of second and third vertebral significantly broader than the pleurals, presence of central plastral fontanelle. 
"Thalassemys moseri" is currently identified as an invalid species. In fact, its holotype, from the Late Kimmeridgian of Solothurn (Switzerland), has been reassigned to Plesiochelys solodurensis by Lapparent de Broin et al. (1996). The specimen from the Oléron Island cannot be assigned to the clade Plesiochelyidae nor Eurysternidae due to numerous characters such as: presence of an extended process anterior to the trigeminal foramen produced by the inferior parietal process; reduced dorsal prefrontal exposure; absence of prefrontal medial contact on the dorsal skull surface; presence of a well-developed nuchal notch; contact of the axillary buttresses with the first pair of peripherals; absence of cervical scutes. The absence of palatal contact of the vomer with the pterygoids and the presence of a ventral ridge on the opisthotic, being developed an enclosed middle ear region, are not shared with the clade Plesiochelyidae. The presence of foramen caroticum laterale and foramen posterior canalis carotici interni formed by the pterygoid; the presence of wide anterior peripherals; the contact of the axillary buttresses with the costal series; the presence of a short anterior lobe in relation to the plastral bridge; and the absence of lateral plastral fontanelles are not shared with Eurysternidae. In addition, the vertebral scutes are not as wide as those recognized in that clade. The presence of laterally open foramen palatinum posterius is shared with some members of Plesiochelyidae (e.g. Plesiochelys planiceps and Plesiochelys solodurensis), but not with others (e.g. Portlandemys mcdowelli).

Several of the discussed characters (e.g. morphology of the carapace; height of the shell; absence of cervical scute; narrower vertebrals; presence of fontanelles between the costal and the peripheral plates; morphology and arrangement of the axillary buttresses), and others (e.g. absence of ornamentation; anteriormost area of the lateral margins of the nuchal convergent towards the anterior region of the carapace; first costal less than twice as wide as long) demonstrates the presence of numerous differences between PMZH A/III 514 and the species of Hylaeochelys.

PMZH A/III 514 also differs from Enaliochelys chelonia in several of the discussed characters (e.g. presence of nuchal notch; absence of cervical scute; narrower vertebrals; very different morphology of the lateral margin of the costal plates).

Therefore, the identification of PMZH A/III 514 as not assignable to any defined taxon is confirmed here. The current knowledge about the basal members of Eucryptodira, together with the review of several taxa included here and in recently published papers (e.g. Joyce, 2000; Pérez-García, 2012, 2014; Pérez-García and Ortega, 2014; Pérez-García et al., 2014; Püntener et al., 2014), allow to characterize this new taxon, named Jurassichelon oleronensis gen. et sp. nov.

\section{Conclusions}

Recent studies concluded that Thalassemys hugii is the only valid species of this genus. It was defined from a specimen from the Late Kimmeridgian of Solothurn (Switzer- land). However, Lydekker (1889b) recognized its presence in the British record, assigning to this species the holotype of Enaliochelys chelonia, from the Kimmeridge Clay Formation of Ely (Cambridgeshire), as well as some elements of another specimen, found in the same formation, but in Devizes (Wiltshire). None of these specimens were figured nor described. The study of all of these specimens refutes their assignment to Thalassemys. The material of Devizes is recognized as belonging to an undetermined basal member of Eucryptodira. However, the validity of Enaliochelys chelonia is confirmed. A diagnosis for this taxon is proposed here for the first time.

Taylor and Benton (1986) mentioned the presence of a well-preserved probable member of the plesiochelyid "Pelobatochelys", from Egmont Bight, in the West coast of the Isle of Purbeck (Dorset, England). This specimen was never studied. It is figured, described and discussed here. This study refutes that preliminary allocation, instead identifying as a representative of Thalassemys. Therefore, this specimen is the only occurrence of Thalassemys currently known outside of its type locality.

A specimen from the Early Tithonian of the Oléron Island (France), attributed by Rieppel (1980) to "Thalassemys moseri", which is currently considered invalid, is revised here. It cannot be assigned to any previously defined taxon, and is assigned to Jurassichelon oleronensis gen. et sp. nov.

The Eucryptodira basal members from the Late Jurassic of Europe were traditionally attributed to three clades: Plesiochelyidae, Eurysternidae and Thalassemydidae (see, for example, Lapparent de Broin, 2001). The presence of $\mathrm{Hyl}$ aeochelys, a taxon not assignable to any of these clades, has recently been recognized in the Late Jurassic of this continent (Pérez-García and Ortega, 2014). The confirmation of the validity of Enaliochelys chelonia, a taxon ignored since the late nineteenth century because of its putative synonymy with Thalassemys hugii, extends this diversity, since it cannot be assigned to any of these clades. In addition, the new genus and species Jurassichelon oleronensis is also not assignable to any of these known groups. This permits to point out a larger diversity of Late Jurassic European eucryptodirans than previously thought, represented by endemic taxa to this continent.

\section{Acknowledgements}

The author thanks Sandra Chapman (NHMUK) and Matt Riley (CAMSM) for access to material, France de Lapparent de Broin (MNHN) for access to photographic documentation of the holotype of Thalassemys hugii and information about this taxon, and editors and reviewers for comments and suggestions. This study has been supported by the SYNTHESYS Project http:/www.synthesys.info/, financed by the European Community Research Infrastructure Action under the FP7 Integrating Activities Programme, and by the Fundação para a Ciência e a Tecnologia (Grant SFRH/ BPD/97806/2013).. 


\section{References}

Andrews, C.A. (1921): On a new chelonian from the Kimmeridge Clay of Swindon. Annals and Magazine of Natural History 7, 145-153.

Bardet, N. (1994): Extinction events among Mesozoic marine reptiles. Historical Biology 7, 313-324. doi: 10.1080/10292389409380462.

Batsch, A.J.G.C. (1788): Versuch einer Anleitung, zur Kennnish und Geschichte der Thiere und Mineralien. Akademische Buchhandlung, Jena, $528 \mathrm{p}$.

Benson R.B.J., Evans M., Smith A.S., Sassoon J., Moore-Faye S., Ketchum, H.F., Forrest, R. (2013): A giant pliosaurid skull from the Late Jurassic of England. PLoS ONE 8, e65989. doi: 10.1371/journal. pone.0065989

Bräm, H. (1965): Die Schildkröten aus dem oberen Jura (Malm) der Gegend von Solothurn. Schweizerische Paläontologische Abhandlungen 83, 1-190.

Fraas, E. (1903): Thalassemys marina E. F aus dem oberen Weissen Jura von Schnaitheim nebst Bemerkungen über des Stammesgeschichte der Schildkröten. Jahreshefte des Vereins für vaterländische Naturkunde in Württemberg 59, 72-104.

Gaffney, E.S. (1975a): A phylogeny and classification of higher categories of turtles. Bulletin of the American Museum of Natural History $155,387-436$.

Gaffney, E.S. (1975b): Solnhofia parsoni, a new cryptodiran turtle from the Late Jurassic of Europe. American Museum Novitates 2576, 1-25.

Gaffney, E.S. (1975c): A taxonomic revision of the Jurassic turtles Portlandemys and Plesiochelys. American Museum Novitates 2574, 1-19.

Joyce, W.G. (2000): The first complete skeleton of Solnhofia parsonsi (Cryptodira, Eurystemidae) from the Upper Jurassic of Germany and its taxonomic implications. Journal of Paleontology 74, 684-700. doi: 10. 1666/0022-3360(2000)074<0684:TFCSOS >2.0.CO;2

Joyce, W.G. (2007): Phylogenetic relationships of Mesozoic turtles. Bulletin of the Peabody Museum of Natural History 48, 3-102. doi: 10.3374/0079-032X(2007)48[3:PROMT]2.0.CO;2

Joyce, W.G., Parham, J.F., Gauthier, J.A. (2004): Developing a protocol for the conversion of rank-based taxon names to phylogenetically defined clade names, as exemplified by turtles. Journal of Paleontology 78, 989-1013. doi: 10.1666/0022-3360(2004)078<0989:DAPFTC $>2$ . $0 . \mathrm{CO} ; 2$

Lapparent de Broin, F. de. (2001): The European turtle fauna from the Triassic to the present. Dumerilia 4, 155-216.

Lapparent de Broin, F. de, Lange-Badré, B., Dutrieux, M. (1996): Nouvelles découvertes de tortues dans le Jurassique Supérieur du Lot (France) et examen du taxon Plesiochelyidae. Revue de Paléobiologie $15,533-570$.

Lydekker, R.A. (1889a): On remains of Eocene and Mesozoic Chelonia and a tooth of (?) Ornithopsis. Quarterly Journal of the Geological Society of London 45, 227-246.

Lydekker, R. (1889b): Catalogue of the fossil Reptilia and Amphibia in the British Museum (Natural History) Part III. The Order Chelonia. Trustees of the British Museum (Natural History), London, $239 \mathrm{p}$.

Lydekker, R. (1904): Vertebrate palaeontology. In: J.E. Marr, A.E. Shipley (eds.), Handbook to the Natural History of Cambridgeshire. Cambridge University Press, Cambridge, pp. 51-70.

Mantell, G.A. (1844): The Medals of Creation; or, First Lessons in Geology and in the study of Organic Remains. H.G. Bohn, London, 2 vol., $1016 \mathrm{p}$.

Owen, R. (1842): Report on British fossil reptiles. Part II. Report of the British Association for the Advancement of Science 11, 60-204.

Pérez-García, A. (2012): High diversity of pancryptodiran turtles in the Lower Cretaceous of Europe. Cretaceous Research 36, 67-82. doi: 10.1016/j.cretres.2012.02.004

Pérez-García, A. (2013): New data on Pelobatochelys, "Enaliochelys" and other basal members of Eucryptodira from the British Late Jurassic record. Abstracts VI Jornadas Internationales sobre Paleontología de Dinosaurios y su entorno, Salas de los Infantes, Burgos, pp. 107-109.

Pérez-García, A. (2014): Revision of the poorly known Dorsetochelys typocardium, a relatively abundant pleurosternid turtle (Paracryptodira) in the Early Cretaceous of Europe. Cretaceous Research 49: 152-162. doi: 10.1016/j.cretres.2014.02.015

Pérez-García, A. (2014): Reinterpretation of the Spanish Late Jurassic "Hispaniachelys prebetica" as an indeterminate plesiochelyid turtle (Testudines, Pancryptodira). Acta Palaeontologica Polonica 59, 879885. doi: 10.4202/app.2012.0115.

Pérez-García, A., Murelaga, X. (2012): Larachelus morla gen. et sp. nov., a new member of the little-known European Early Cretaceous record of stem cryptodiran turtles. Journal of Vertebrate Paleontology 32, 1293-1302. doi:10.1080/02724634.2012.694592.

Pérez-García, A., Ortega, F. (2014): A new species of the turtle Hylaeochelys (Eucryptodira) outside its known geographic and stratigraphic ranges of distribution. Comptes Rendus Palevol 13, 183-188. doi: 10.1016/j.crpv.2013.10.009.

Pérez-García, A., Gasulla, J.M., Ortega, F. (2014): A new species of Brodiechelys (Testudines, Pan-Cryptodira) from the Early Cretaceous of Spain: Systematic and palaeobiogeographic implications. Acta Palaeontologica Polonica 59, 333-342. doi: 10.4202/app.2012.0059.

Pérez-García, A., Royo-Torres, R., Cobos, A. (in press): A new European Late Jurassic pleurosternid (Testudines, Paracryptodira) and its inclusion in a new hypothesis on the phylogeny of the paracryptodiran taxa. Journal of Systematic Palaeontology. doi: 10.1080/14772019.2014.911212

Püntener, C., Billon-Bruyat, J.-P., Bocat, L., Berger, J.-P., Joyce, W.G. (2014): Taxonomy and phylogeny of the turtle Tropidemys langii Rütimeyer, 1873 based on new specimens from the Kimmeridgian of the Swiss Jura Mountains. Journal of Vertebrate Paleontology 34: 353-374. doi: 10.1080/02724634.2013.804412

Rieppel, O. (1980): The skull of the Upper Jurassic cryptodire turtle Thalassemys with a reconsideration of the chelonian braincase. Palaeontographica Abt. A 171, 105-140.

Rütimeyer, L. (1873): Die fossilen Schildkröten von Solothurn. Neue Denkschrift der Allgemeinen Schweizerischen Naturforschenden Gesellschaft 25, 1-185.

Seeley, H.G. (1869): Index to the fossil remains of Aves, Ornithosauria and Reptilia from the Secondary System of strata arranged in the Woodwardian Museum of the University of Cambridge. Bell and Co., Deighton, $143 \mathrm{p}$.

Seeley, H.G. (1875): Note on Pelobatochelys blakii and other vertebrate fossils exhibited by the Rev. J. G. Blake in illustration of his paper on the Kimmeridge Clay. Quarterly Journal of the Geological Society of London. 31, 234-237.

Sterli, J., de la Fuente, M.S. (2011): A new turtle from the La Colonia Formation (Campanian-Maastrichtian), Patagonia, Argentina, with remarks on the evolution of the vertebral column in turtles. Palaeontology 54, 63-78. doi:10.1111/j.1475-4983.2010.01002.x

Taylor, M.A., Benton, M.J. (1986): Reptiles from the Upper Jurassic Clay (Kimmeridgean, Upper Jurassic) of the vicinity of Egmont Bight, Dorset. Proceedings of the Dorset Natural History and Archaeological Society 107, 121-125.

Tong, H., Danilov, I., Ye, Y., Ouyang, H., Peng, G., Li, K. (2012): A revision of xinjiangchelyid turtles from the Late Jurassic of Sichuan Basin, China. Annales de Paléontologie 98, 73-114. doi: 10.1016/j. annpal.2012.01.001.

Young, C.C., and Chow, M.C. (1953): New fossil reptiles from Szechuan, China. Acta Scientica Sinica 2, 216-243.

Zittel, K. A. (1902): Text-book of Palaeontology. Macmillan and Co., London, $283 \mathrm{p}$. 